\title{
Ventilatory Function in Relation to Mining Experience and Smoking in a Random Sample of Miners and Non-miners in a Witwatersrand Town ${ }^{1}$
}

\author{
G. K. SLUIS-CREMER, L. G. WALTERS, and H. S. SICHEL \\ From the Miners' Medical Bureau, the Pneumoconiosis Research Unit \\ and the Operational Research Bureau, fohannesburg
}

The ventilatory capacity of a random sample of men over the age of 35 years in the town of Carletonville was estimated by the forced expiratory volume and the peak expiratory flow rate.

Five hundred and sixty-two persons were working or had worked in gold-mines and 265 had never worked in gold-mines.

No difference in ventilatory function was found between the miners and non-miners other than that due to the excess of chronic bronchitis in miners.

A description of the survey conducted in the town of Carletonville is given in the previous communication (Sluis-Cremer, Walters, and Sichel, 1967). The object was to determine whether chronic bronchitis occurred more frequently among a dustexposed group of miners and ex-miners than in a non-mining group, both living in the same town where atmospheric pollution is virtually absent.

Both groups consisted of men over the age of 35 years. The sample was drawn from a population who are socio-economically homogeneous.

There were 562 persons in the dust-exposed group and 265 without dust exposure. Full details of the age, height, weight, smoking habit, and other characteristics of the two groups are described in detail in the previous paper. Suffice it to say that the dust-exposed group was slightly younger (average age 44.9 years compared to 46.5 years), slightly shorter $(69 \cdot 1$ in., $175 \mathrm{~cm}$.; and 69.5 in., $176 \mathrm{~cm}$.), and slightly heavier $(177.4 \mathrm{lb} ., 80 \mathrm{~kg}$.; and $172.8 \mathrm{lb} ., 78 \mathrm{~kg}$.). In addition, the dust-exposed group contained more smokers and fewer persons who had never smoked than the group without exposure to dust. The average amount smoked by present smokers in the two groups was, however, virtually identical.

The ventilatory function in the two groups was

\footnotetext{
1This study was carried out under the auspices of the Pneumoconiosis Research Unit of the South African Council for Scientific and Industrial Research.
}

Received for publication April 29, 1966. estimated by the one-second forced expiratory volume $($ F.E.V.1.0 $)$ and the peak expiratory flow rate (P.E.F.R.). The purpose was to determine whether any differences existed between the dustexposed and non-dust-exposed groups and, if such differences did exist, whether they could be ascribed to the increased prevalence of chronic bronchitis which has been shown in the dust-exposed group or whether there was a loss of ventilatory function not ascribable to chronic bronchitis.

Throughout this paper the term 'chronic bronchitis' is used in the sense of definition $I$, as given in the previous paper.

\section{Methods}

All the observations and measurements were made by the same field officer (a senior mine hygiene officer) who had been thoroughly trained in the use, care, and calibration of his instruments.

The instruments were housed in a Volkswagen Kombe converted into a mobile laboratory unit. Measurements were made with the subjects in the sitting position.

Forced Expiratory Volume The Poulton spirometer was used to measure the F.E.V.1.0. The instrument had been checked and calibrated in the laboratories of the Medical Research Council Pneumoconiosis Research Unit at Cardiff, South Wales. Mrs. McDermott of that Unit also provided two transistorized battery-operated timers which 
proved highly successful. All measurements could therefore be performed in the mobile unit.

Five measurements were made on each subject and the results are presented separately as the maximum value and as the mean of the last three readings.

The temperature of the water in the spirometer was recorded ior every new subject, and appropriate corrections were made from a table prepared for the particular instrument. Figures were corrected to $37^{\circ} \mathrm{C}$. saturated with water vapour (B.T.P.S.). The instrument was calibrated daily with the simple calibrating device described by McKerrow, McDermott, and Gilson (1960).

Peak Expiratory Flow Rate The P.E.F.R. was measured by the Wright peak flowmeter. Two instruments were used which were calibrated against each other frequently. Five measurements were made on each subject and the results are expressed as the maximum reading and as the mean of readings 3,4 , and 5 .

\section{Results}

Forced Expiratory Volume Table I shows the frequency distribution of the mean F.E.V. for the four groups, dust-exposed with and without chronic bronchitis and non-dust-exposed with and without chronic bronchitis.

The differences between the averages of the mean

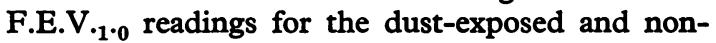
dust-exposed groups both with and without chronic bronchitis are not significant at the $5 \%$ level of probability.

On the other hand, when those persons with chronic bronchitis and those without are pooled in two groups, as in Table II, the average F.E.V $\cdot_{1 \cdot 0}$ of subjects with chronic bronchitis is 0.51 . lower than that of the non-bronchitis group. This difference is highly significant $(\mathbf{P}<0.00 \mathrm{r})$.

The same conclusion is reached if the observations are presented in terms of the maximal (of the last three readings) recorded for the F.E.V.1.0 as shown in Table III.

Neither in the chronic bronchitis group nor in the group without bronchitis is there a difference significant at the $5 \%$ level of probability between the dust-exposed and non-dust-exposed groups.

Pooling the groups of persons with chronic bronchitis and persons free of bronchitis gives the results shown in Table IV.

Once again the average of the maximum F.E.V.1.0 for the chronic bronchitis group is 0.51 . lower and the difference is highly significant $(P<0.001)$.

\section{TABLE I}

Mean F.E.V $\cdot_{1 \cdot 0}$ IN Dust-exposed and Non-Dust-exposed Groups With and Without Chronic Bronchitis (DEFINITION I)

\begin{tabular}{|c|c|c|c|c|c|c|c|c|}
\hline \multirow{2}{*}{\multicolumn{5}{|c|}{$\underset{(l .)}{\text { Mean }} \underset{\text { F. E. } V}{\cdot_{1 \cdot 0}}$}} & \multicolumn{2}{|c|}{ Chronic Bronchitis } & \multicolumn{2}{|c|}{ No Bronchitis } \\
\hline & & & & & Dust-exposed & No Exposure & Dust-exposed & No Exposure \\
\hline $\begin{array}{lr}0 & -0.49 \\
0.50-0.99 \\
1 \cdot 00-1.49 \\
1 \cdot 50-1.99 \\
2 \cdot 00-2.49 \\
2.50-2.99\end{array}$ & $\begin{array}{l}\ldots \\
\cdots \\
\cdots \\
\cdots \\
\cdots\end{array}$ & $\begin{array}{l}\ldots \\
\ldots \\
\ldots \\
\cdots \\
\ldots \\
.\end{array}$ & $\begin{array}{l}\ldots \\
\ldots \\
\ldots \\
\ldots \\
\ldots\end{array}$ & $\begin{array}{l}\cdots \\
\cdots \\
\cdots \\
\cdots \\
\cdots\end{array}$ & $\begin{array}{r}1(0.5 \%) \\
3(1.4 \%) \\
9(4.1 \%) \\
22(10.1 \%) \\
32(14.7 \%) \\
54(24.9 \%)\end{array}$ & $\begin{array}{c}-\overline{1}(1 \cdot 9 \%) \\
4(7.7 \%) \\
6(11 \cdot 5 \%) \\
7(13.5 \%) \\
8(15.4 \%)\end{array}$ & $\begin{array}{rc} & - \\
3 & (0.9 \%) \\
3 & (0.9 \%) \\
\text { I1 } & (3.4 \%) \\
17 & (5.2 \%) \\
65 & (19.8 \%)\end{array}$ & $\begin{array}{rc}- & - \\
1 & (0.5 \%) \\
4 & (1.9 \%) \\
5 & (2.4 \%) \\
18 & (8.5 \%) \\
39 & (18.5 \%)\end{array}$ \\
\hline $\begin{array}{l}3 \cdot 00-3 \cdot 49 \\
3 \cdot 50-3 \cdot 99 \\
4 \cdot 00-4 \cdot 49 \\
4 \cdot 50-4 \cdot 99 \\
5 \cdot 00-5 \cdot 49 \\
5 \cdot 50-5 \cdot 99\end{array}$ & $\begin{array}{l}\ldots \\
\cdots \\
\cdots \\
\cdots \\
\ldots\end{array}$ & $\begin{array}{l}\ldots \\
\cdots \\
\cdots \\
\cdots \\
\cdots\end{array}$ & $\begin{array}{l}\ldots \\
\ldots \\
\ldots \\
\ldots \\
\ldots\end{array}$ & $\begin{array}{l}\cdots \\
\cdots \\
\cdots \\
\cdots \\
\cdots\end{array}$ & $\begin{array}{r}54(24.9 \%) \\
27(12.5 \%) \\
9(4.1 \%) \\
3(1.4 \%) \\
3 \quad(1.4 \%) \\
-\quad-\end{array}$ & $\begin{array}{r}17(32.7 \%) \\
7(13.5 \%) \\
1 \quad(1.9 \%) \\
1 \quad(1.9 \%) \\
-\quad-\end{array}$ & $\begin{array}{r}87(26.4 \%) \\
86(26 \cdot 1 \%) \\
35(10.6 \%) \\
17(5.2 \%) \\
4(1.2 \%) \\
1(0.3 \%)\end{array}$ & $\begin{array}{r}56(26 \cdot 5 \%) \\
48(22 \cdot 7 \%) \\
27(12.8 \%) \\
9(4.3 \%) \\
4 \quad(1.9 \%) \\
-\quad-\end{array}$ \\
\hline Total & . & .. & .. & . & $217(100 \%)$ & $52(100 \%)$ & $329(100 \%)$ & $211(100 \%)$ \\
\hline Refusals . . & . & .. & . & . & $4-$ & $-\quad-$ & $12-$ & - \\
\hline Grand Total & .. & .. & .. & . & 221 & 52 & 341 & 213 \\
\hline $\begin{array}{l}\text { Average (1.) } \\
\text { S.D. (1.) .. }\end{array}$ & $\begin{array}{l}\cdots \\
\cdots\end{array}$ & $\begin{array}{l}. \\
\ldots\end{array}$ & $\begin{array}{l}\cdots \\
\cdots\end{array}$ & $\begin{array}{l}\cdots \\
\cdots\end{array}$ & $\begin{array}{l}2 \cdot 84 \\
0.84\end{array}$ & $\begin{array}{l}2 \cdot 77 \\
0.85\end{array}$ & $\begin{array}{l}3.35 \\
0.77\end{array}$ & $\begin{array}{l}3 \cdot 33 \\
0.79\end{array}$ \\
\hline
\end{tabular}




\section{TABLE II}

Mean F.E.V.1.0 IN Those With and Without Chronic BRONCHITIS (DEFINITION I), DUST-EXPOSED AND NON-DUSTEXPOSED GROUPS COMBINED

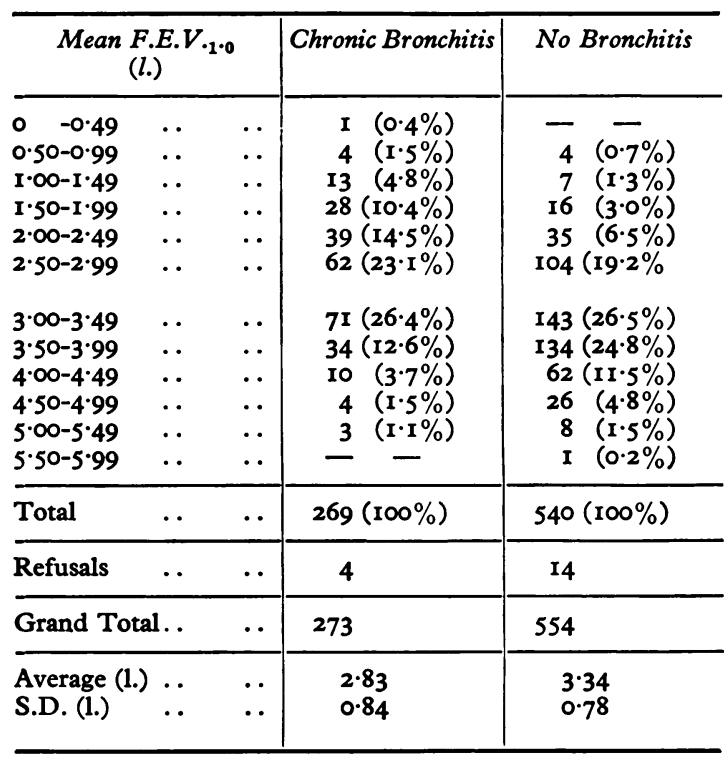

TABLE IV

Maximum F.E.V.1.0 IN Those With and Without Chronic BRoNCHITIS (DEFINITION I), DUST-EXPOSED AND NON-DUSTEXPOSED GROUPS COMBINED

\begin{tabular}{|c|c|c|c|c|}
\hline \multicolumn{3}{|c|}{$\underset{(l .)}{\operatorname{Max}} \underset{F . E . V_{\cdot 1 \cdot 0}}{ }$} & Chronic Bronchitis & No Bronchitis \\
\hline $\begin{array}{l}0 \quad-0.49 \\
0.50-0.99 \\
1 \cdot 00-1 \cdot 49 \\
1 \cdot 50-1 \cdot 99 \\
2 \cdot 00-2 \cdot 49 \\
2 \cdot 50-2 \cdot 99\end{array}$ & $\begin{array}{l}\ddot{\ldots} \\
\ddot{\ldots} \\
\ddot{*} \\
\ldots\end{array}$ & $\begin{array}{l}\ldots \\
\ldots \\
\ldots \\
\ldots \\
\ldots \\
. .\end{array}$ & $\begin{array}{r}1(0.4 \%) \\
4(1.5 \%) \\
10(3.7 \%) \\
22(8.2 \%) \\
40(1.9 \%) \\
60(22.3 \%)\end{array}$ & $\begin{array}{rc}- & - \\
3 & (0.5 \%) \\
7 & (1.3 \%) \\
16 & (3.0 \%) \\
28 & (5.2 \%) \\
93 & (17.2 \%)\end{array}$ \\
\hline $\begin{array}{l}3 \cdot 00-3 \cdot 49 \\
3 \cdot 50-3 \cdot 99 \\
4 \cdot 00-4 \cdot 49 \\
4 \cdot 50-4 \cdot 99 \\
5 \cdot 00-5 \cdot 49 \\
5 \cdot 50-5 \cdot 99\end{array}$ & $\begin{array}{l}\ldots \\
\ldots \\
\ldots \\
\cdots \\
\ldots\end{array}$ & $\begin{array}{l}\cdots \\
\cdots \\
\cdots \\
\cdots \\
\cdots\end{array}$ & $\begin{array}{r}70(26.0 \%) \\
41(15.2 \%) \\
13(4.8 \%) \\
5(1 \cdot 9 \%) \\
3 \quad(1.1 \%) \\
-\quad-\end{array}$ & $\begin{array}{r}141(26.1 \%) \\
138(25.5 \%) \\
69(12.8 \%) \\
36(6.7 \%) \\
8(1.5 \%) \\
1 \quad(0.2 \%)\end{array}$ \\
\hline Total & .. & . & $269(100 \%)$ & $540(100 \%)$ \\
\hline Refusals & . & .. & 4 & 14 \\
\hline Grand Tot & al. & . & 273 & 554 \\
\hline $\begin{array}{l}\text { Average (1. } \\
\text { S.D. (1.) }\end{array}$ & $\begin{array}{l}\cdots \\
\ldots\end{array}$ & $\begin{array}{l}\cdots \\
\cdots\end{array}$ & $\begin{array}{l}2.91 \\
0.84\end{array}$ & $\begin{array}{l}3.4 I \\
0.78\end{array}$ \\
\hline
\end{tabular}

TABLE III

Maximum F.E.V.1.0 IN Dust-exposed and Non-Dust-exposed Groups WITh aNd Without Chronic Bronchitis (DEFINITION I)

\begin{tabular}{|c|c|c|c|c|c|c|c|c|}
\hline \multirow{2}{*}{\multicolumn{5}{|c|}{$\underset{(l .)}{\operatorname{Maximum} F \cdot E \cdot V_{\cdot 1 \cdot 0}}$}} & \multicolumn{2}{|c|}{ Chronic Bronchitis } & \multicolumn{2}{|c|}{ No Bronchitis } \\
\hline & & & & & Dust-exposed & No Exposure & Dust-exposed & No Exposure \\
\hline $\begin{array}{lr}0 & -0.49 \\
0.50-0.99 \\
1 \cdot 00-1 \cdot 49 \\
1 \cdot 50-1.99 \\
2 \cdot 00-2.49 \\
2.50-2.99\end{array}$ & $\begin{array}{l}. \\
. \\
. . \\
. \\
. \\
.\end{array}$ & $\begin{array}{l}\cdots \\
\ldots \\
\ldots \\
\cdots \\
\cdots\end{array}$ & $\begin{array}{l}\ldots \\
\ldots \\
\cdots \\
\ldots \\
\cdots\end{array}$ & $\begin{array}{l}\ldots \\
\cdots \\
\cdots \\
\cdots \\
\ldots\end{array}$ & $\begin{array}{r}1(0.5 \%) \\
3 \\
6(1.4 \%) \\
6(2.7 \%) \\
18(8.3 \%) \\
31(14.3 \%) \\
54(24.9 \%)\end{array}$ & $\begin{array}{lc}- & - \\
\text { I } & (1 \cdot 9 \%) \\
4 & (7 \cdot 7 \%) \\
4 & (7 \cdot 7 \%) \\
9 & (17 \cdot 3 \%) \\
6(11.6 \%)\end{array}$ & $\begin{array}{rc}- & - \\
2 & (0.6 \%) \\
3 & (0.9 \%) \\
11 & (3.3 \%) \\
12 & (3.6 \%) \\
57(17.3 \%)\end{array}$ & $\begin{array}{rc}- & - \\
1 & (0.5 \%) \\
4 & (1 \cdot 9 \%) \\
5 & (2 \cdot 3 \%) \\
16 & (7.6 \%) \\
36 & (17 \cdot 1 \%)\end{array}$ \\
\hline $\begin{array}{l}3 \cdot 00-3 \cdot 49 \\
3 \cdot 50-3 \cdot 99 \\
4 \cdot 00-4 \cdot 49 \\
4 \cdot 50-4 \cdot 99 \\
5 \cdot 00-5 \cdot 49 \\
5 \cdot 50-5 \cdot 99\end{array}$ & $\begin{array}{l}\cdots \\
\cdots \\
\cdots \\
\cdots \\
\cdots\end{array}$ & $\begin{array}{l}\ldots \\
\cdots \\
\cdots \\
\cdots \\
\cdots\end{array}$ & $\begin{array}{l}\ldots \\
\cdots \\
\cdots \\
\cdots \\
\cdots\end{array}$ & $\begin{array}{l}\ldots \\
\cdots \\
\cdots \\
\cdots \\
\cdots \\
.\end{array}$ & $\begin{aligned} & 51(23.5 \%) \\
& 35(16.1 \%) \\
& \text { II }(5.1 \%) \\
& 4(1.8 \%) \\
& 3 \quad(1.4 \%) \\
&-\quad-\end{aligned}$ & $\begin{array}{r}19(36 \cdot 5 \%) \\
6(11.6 \%) \\
2(3.8 \%) \\
1 \quad(1.9 \%) \\
-\quad- \\
-\quad-\end{array}$ & $\begin{array}{r}87(26.5 \%) \\
88(26.8 \%) \\
43(13.1 \%) \\
21 \quad(6.4 \%) \\
4 \quad(1.2 \%) \\
1 \quad(0.3 \%)\end{array}$ & $\begin{array}{l}54(25 \cdot 6 \%) \\
50(23 \cdot 7 \%) \\
26(12 \cdot 3 \%) \\
15(7 \cdot 1 \%) \\
4 \quad(1 \cdot 9 \%) \\
-\quad-\end{array}$ \\
\hline Total & .. & .. & . & .. & $217(100 \%)$ & $52(100 \%)$ & $329(100 \%)$ & $211(100 \%)$ \\
\hline Refusals .. & . & . & . & . & 4 & 一 & 12 & 2 \\
\hline Grand Total & .. & .. & . & . & 221 & 52 & $34 I$ & 213 \\
\hline $\begin{array}{l}\text { Average (1.) } \\
\text { S.D. (1.) . }\end{array}$ & $\begin{array}{l}\cdots \\
\ldots\end{array}$ & $\ddot{\ldots}$ & $\ddot{m}$ & $\begin{array}{l}. . \\
\ldots\end{array}$ & $\begin{array}{l}2 \cdot 94 \\
0 \cdot 84\end{array}$ & $\begin{array}{l}2.82 \\
0.85\end{array}$ & $\begin{array}{l}3.43 \\
0.76\end{array}$ & $\begin{array}{l}3.38 \\
0.81\end{array}$ \\
\hline
\end{tabular}


TABLE V

Mean P.E.F.R. in Dust-exposed and Non-dust-exposed Groups With aNd Without Chronic Bronchitis (DEFINITION I)

\begin{tabular}{|c|c|c|c|c|c|c|c|c|c|}
\hline \multirow{2}{*}{\multicolumn{6}{|c|}{$\begin{array}{c}\text { Mean P.E.F.R. } \\
(\text { l. } / \text { min. })\end{array}$}} & \multicolumn{2}{|c|}{ Chronic Bronchitis } & \multicolumn{2}{|c|}{ No Bronchitis } \\
\hline & & & & & & \multirow{2}{*}{$\frac{\text { Dust-exposed }}{\text { I }(0.5 \%)}$} & No Exposure & Dust-exposed & No Exposure \\
\hline $50-99$ & .. & .. & . & .. & .. & & - - & - - & I $(0.5 \%)$ \\
\hline 100-194 & .. & .. & . & .. & . & I $(0.5 \%)$ & I $(1 \cdot 9 \%)$ & $4(\mathrm{I} \cdot 2 \%)$ & I $(0.5 \%)$ \\
\hline $150-199$ & .. & .. & . & . & .. & $3(1 \cdot 4 \%)$ & $4(7 \cdot 7 \%)$ & $2(0.6 \%)$ & $-\quad-$ \\
\hline $200-249$ & $\cdots$ & . & $\cdots$ & $\cdots$ & $\cdots$ & $9(4.1 \%)$ & $2(3.8 \%)$ & I $(0.3 \%)$ & $2(0.9 \%)$ \\
\hline $250-299$ & $\cdots$ & . & $\cdots$ & $\cdots$ & $\cdots$ & $8(3.7 \%)$ & $3(5.8 \%)$ & $3(0.9 \%)$ & $3(1 \cdot 4 \%)$ \\
\hline $300-349$ & .. & . & $\cdots$ & . & $\cdots$ & $17(7 \cdot 8 \%)$ & $3(5 \cdot 8 \%)$ & $7(2 \cdot 1 \%)$ & $5(2 \cdot 4 \%)$ \\
\hline $350-399$ & . & . & $\cdots$ & $\cdots$ & . & $25(\mathrm{II} \cdot 4 \%)$ & $4(7 \cdot 7 \%)$ & I5 $(4.4 \%)$ & $7(3.3 \%)$ \\
\hline $400-449$ & . & $\cdots$ & $\cdots$ & . & $\cdots$ & $41(18 \cdot 8 \%)$ & I I $(2 I \cdot I \%)$ & $28(8 \cdot 2 \%)$ & $12(5 \cdot 7 \%)$ \\
\hline $450-499$ & .. & $\ldots$ & . & . & $\cdots$ & $40(18 \cdot 3 \%)$ & $3(5.8 \%)$ & $76(22 \cdot 4 \%)$ & $47(22 \cdot 2 \%)$ \\
\hline $500-549$ & $\cdots$ & . & $\cdots$ & . & $\cdots$ & $45(20 \cdot 6 \%)$ & II $(2 I \cdot I \%)$ & $81(23.9 \%)$ & $53(25 \cdot 0 \%)$ \\
\hline $550-599$ & .. & . & . & .. & $\cdots$ & $18(8.2 \%)$ & $7(13.5 \%)$ & $68(20 \cdot 1 \%)$ & $4 I(19.3 \%)$ \\
\hline $600-649$ & .. & . & . & .. & . & $8(3.7 \%)$ & $3(5.8 \%)$ & $35(10.3 \%)$ & $27(12.7 \%)$ \\
\hline $650-699$ & .. & $\cdots$ & . & .. & . & I $(0.5 \%)$ & $-\quad-$ & $14(4.1 \%)$ & $9(4.2 \%)$ \\
\hline $700-749$ & .. & .. & . & . & .. & - - & $-\quad-$ & $5(1 \cdot 5 \%)$ & $3(1 \cdot 4 \%)$ \\
\hline $750-799$ & . & $\cdots$ & $\cdots$ & . & $\cdots$ & I $(0.5 \%)$ & - & $-\quad-$ & I $(0.5 \%)$ \\
\hline Total & . & $\cdots$ & $\cdots$ & . & $\cdots$ & $218(100 \%)$ & $52(100 \%)$ & $339(100 \%)$ & $212(100 \%)$ \\
\hline Refusals & .. & $\cdots$ & $\cdots$ & $\cdots$ & $\cdots$ & 3 & - & 2 & $\mathbf{I}$ \\
\hline Grand $T$ & otal & $\cdots$ & . & . & . & 221 & 52 & $34 I$ & 213 \\
\hline Average & $(1 . / \mathrm{m}$ & & $\cdots$ & $\cdots$ & $\cdots$ & $\begin{array}{l}443 \cdot 1 \\
107 \cdot 6\end{array}$ & $\begin{array}{l}429 \cdot 3 \\
133.6\end{array}$ & $\begin{array}{r}513.9 \\
06.0\end{array}$ & $\begin{array}{r}520.5 \\
08.2\end{array}$ \\
\hline S.D. $(1 . / \mathrm{n}$ & min.) & . & $\cdots$ & - & $\cdots$ & $107 \cdot 6$ & $133 \cdot 6$ & $96 \cdot 9$ & \\
\hline
\end{tabular}

Peak Expiratory Flow Rate Table V shows the mean P.E.F.R. for the four groups of persons with and without chronic bronchitis in the dustexposed and non-dust-exposed groups.

The averages of the mean P.E.F.R.s for the dust-exposed and non-dust-exposed groups are not significantly different from each other at the $5 \%$ level of probability.

The combination of those with chronic bronchitis and those without is shown in Table VI.

The chronic bronchitis group has an average mean P.E.F.R. $76 \mathrm{l} . / \mathrm{min}$. lower than that of the group free of bronchitis. This difference is highly significant $(P<0.001)$.

Similarly, the maximum values for the P.E.F.R. showed no significant differences at the $5 \%$ level between dust-exposed and non-dust-exposed persons among those with or without bronchitis.

The averages and standard deviations are shown in Table VII.

Similarly, when the values for the dust-exposed and non-dust-exposed groups are pooled for the chronic bronchitis and non-bronchitis groups, the chronic bronchitis group shows an average P.E.F.R.
$74 \mathrm{l} . / \mathrm{min}$. lower than that of the non-bronchitis group (Table VIII). This difference is highly significant $(P<0.001)$.

The mean F.E.V.1.0 was correlated with the phlegm grade for the dust-exposed and non-dustexposed persons in both the chronic bronchitis and non-bronchitis groups. This is shown in Table IX.

This should provide an indication of any differences in the degree of severity of ventilatory impairment between chronic bronchitic miners and non-miners.

The phlegm grades were derived from the questionnaire (see this journal, p. 5) in the following manner. Only subjects who admitted to bringing up phlegm on most days for as much as three months each year (question 10) were included in grades I or II. For grade I, either question 6 or 8 was answered in the affirmative in addition to question 10.

Question 6 reads 'Do you usually bring up any phlegm from your chest first thing in the morning in the winter (on getting up) ?'

Question 8 reads 'Do you bring up any phlegm from your chest during the day or at night in the winter?' 
TABLE VI

Mean P.E.F.R. IN Those WITh and Without Chronic BRONChITIS (DEFINITION I), DUST-EXPOSED AND NON-DUSTEXPOSED GROUPS COMBINED

\begin{tabular}{|c|c|c|c|c|}
\hline \multicolumn{3}{|c|}{$\begin{array}{c}\text { Mean P.E.F.R. } \\
(l . / m i n .)\end{array}$} & Chronic Bronchitis & No Bronchitis \\
\hline 50- 99 & .. & $\ldots$ & I $(0.4 \%)$ & I $(0.2 \%)$ \\
\hline $100-149$ & $\ldots$ & $\therefore$ & $2(0.7 \%)$ & $5(0.9 \%)$ \\
\hline I 50-199 & . & $\ldots$ & $7(2.6 \%)$ & $2(0.4 \%)$ \\
\hline $200-249$ & .. & $\cdots$ & II $(4.1 \%)$ & $3(0.5 \%)$ \\
\hline $250-299$ & $\cdots$ & $\cdots$ & I I $(4 \cdot 1 \%)$ & $6(I \cdot I \%)$ \\
\hline $300-349$ & - & .. & $20(7 \cdot 4 \%)$ & $12(2 \cdot 2 \%)$ \\
\hline $350-399$ & - & $\ldots$ & $29(10.7 \%)$ & $22(4.0 \%)$ \\
\hline $400-449$ & . & $\ldots$ & $52(19.3 \%)$ & $40(7 \cdot 3 \%)$ \\
\hline $450-499$ & .. & $\ldots$ & $43(15 \cdot 9 \%)$ & $123(22 \cdot 3 \%)$ \\
\hline $500-549$ & $\cdots$ & $\cdots$ & $56(20 \cdot 7 \%)$ & $134(24 \cdot 3 \%)$ \\
\hline $550-599$ & - & $\ldots$ & $25(9.2 \%)$ & $\log (19.8 \%)$ \\
\hline $600-649$ & - & . & II $(4.1 \%)$ & $62(\mathrm{II} \cdot 2 \%)$ \\
\hline $650-699$ & - & $\cdots$ & I $(0.4 \%)$ & $23(4.2 \%)$ \\
\hline $700-749$ & . & .. & $-\quad-$ & $8(1 \cdot 4 \%)$ \\
\hline $750-799$ & $\cdots$ & $\cdots$ & I $(0.4 \%)$ & I $(0.2 \%)$ \\
\hline Total & $\cdots$ & $\cdots$ & $270(100 \%)$ & $551(100 \%)$ \\
\hline Refusals & $\cdots$ & $\cdots$ & 3 & 3 \\
\hline \multicolumn{2}{|c|}{ Grand Total. . } & $\cdots$ & 273 & 554 \\
\hline \multirow{2}{*}{\multicolumn{2}{|c|}{$\begin{array}{l}\text { Average (1./min.) } \\
\text { S.D. (1./min.) }\end{array}$}} & $\ldots$ & $440 \cdot 4$ & $516 \cdot 4$ \\
\hline & & $\cdots$ & II2.9 & $97 \cdot 4$ \\
\hline
\end{tabular}

TABLE VII

Average Maximum P.E.F.R. In Dust-exposed aND NonDUST-EXPOSED GROUPS WITH AND WITHOUT CHRONIC BRONCHITIS (DEFINITION I)

\begin{tabular}{cc|c|c}
\hline & $\begin{array}{c}\text { Average } \\
\text { Max. P.E.F.R. } \\
\text { (l./min. })\end{array}$ & S.D. \\
\hline Chronic bronchitis & & & \\
Dust-exposed .. & $\ldots$ & $456 \cdot 2$ & $106 \cdot 5$ \\
Non-dust-exposed & $\ldots$ & 438.9 & $131 \cdot 1$ \\
No bronchitis & & 524.4 & $97 \cdot 3$ \\
Dust-exposed .. & $\ldots$ & $531 \cdot 4$ & 100.6 \\
Non-dust-exposed & $\ldots$ & 53 & \\
\hline
\end{tabular}

\section{TABLE VIII}

Average Maximum P.E.F.R. In Those With aND Without Chronic Bronchitis (DEFINITION I), DUST-EXPosed AND NON-DUST-EXPOSED GROUPS COMBINED

\begin{tabular}{|c|c|c|c|}
\hline & & $\begin{array}{c}\text { Average } \\
\text { Max. P.E.F.R. } \\
\text { (l./min. })\end{array}$ & S.D. \\
\hline $\begin{array}{l}\text { Chronic bronchitis } \\
\text { No bronchitis .. }\end{array}$ & $\begin{array}{l}\ldots \\
\ldots\end{array}$ & $\begin{array}{l}452 \cdot 8 \\
527 \cdot 0\end{array}$ & $\begin{array}{r}111 \cdot 6 \\
98 \cdot 6\end{array}$ \\
\hline
\end{tabular}

For grade II, both questions 6 and 8 were answered in the affirmative in addition to question 10.

Differences between the means of the F.E.V.1.0 $s$ for persons reporting phlegm grade II in the dustexposed and non-dust-exposed groups exist for both bronchitics and non-bronchitics. Among the former the F.E.V.1.0 was 0.35 l. higher in the dustexposed group, and among non-bronchitics it was 0.761 . lower in the dust-exposed group. These differences are, however, not significant at the $5 \%$ level of probability.

There is no significant difference between the means of the F.E.V. $\cdot_{1 \cdot 0}$ s for the dust-exposed and non-dust-exposed groups without bronchitis and without complaint of phlegm (grade $\circ$ phlegm).

The presence of Io persons claiming grade I phlegm and four with grade II phlegm among the group free of bronchitis may be considered as something of an anomaly. These are persons who claim to produce phlegm on most days for as much as three months each year but deny they cough to that degree; they are, therefore, according to definition treated as non-bronchitics. Their average F.E.V.1.0 are not important because of the few persons involved.

Similar results are shown in Table $\mathrm{X}$ which were obtained by correlating the P.E.F.R. with the phlegm grade in the same way.

Among the dust-exposed with phlegm grade II the mean P.E.F.R. is $56.1 \mathrm{l} / \mathrm{min}$. higher for the bronchitics and $1001 . / \mathrm{min}$. lower for the nonbronchitics than in the corresponding non-dusty groups. Neither these differences nor the smaller differences for phlegm grade I are statistically significant.

No significant difference exists between the dustexposed and non-dust-exposed persons who deny any phlegm $(515.11 . / \mathrm{min}$. and $521 \cdot 21 . / \mathrm{min}$. respectively).

Tables IX and $\mathrm{X}$ show important differences in both F.E.V.1.0 and P.E.F.R., between grade o, grade I, and grade II phlegm classes for both the dust-exposed and non-dust-exposed groups.

In the dust-exposed group, the F.E.V.1.0 for grade 0 phlegm is 3.35 1., for grade I 3.08 1., and for grade II 2.59 litres. The difference between the F.E.V $\cdot_{1 \cdot 0}$ for grade $O$ and grade I phlegm is significant at the $I \%$ and that between grade $I$ and grade II at $0.001 \%$ levels of significance. In the non-dustexposed group the figures are $3.331 ., 2.991$., and 2.24 1. respectively. In this case the difference between grade $O$ and grade I phlegm is significant at the $I \%$ level and that between grade I phlegm and grade II phlegm at the $5 \%$ level of significance.

Similar results are shown in Table $\mathrm{X}$ giving the 
TABLE IX

Mran F.E.V.1.0 Correlated with Philgm Grade in Those With and Without Chronic Bronchitis (DEFINITION I)

\begin{tabular}{|c|c|c|c|c|c|c|c|c|c|c|c|c|c|c|}
\hline \multirow{2}{*}{\multicolumn{3}{|c|}{$\underset{(l .)}{\operatorname{Mean} \underset{F}{F} \boldsymbol{V}_{\cdot 1 \cdot 0}}$}} & \multicolumn{6}{|c|}{ Chronic Bronchitis } & \multicolumn{6}{|c|}{ No Bronchitis } \\
\hline & & & \multicolumn{3}{|c|}{ Dust-exposed } & \multicolumn{3}{|c|}{ No Exposure } & \multicolumn{3}{|c|}{ Dust-exposed } & \multicolumn{3}{|c|}{ No Exposure } \\
\hline \multicolumn{2}{|c|}{ Phlegm grade } & $\cdots$ & 0 & $\mathbf{I}$ & 2 & 0 & $\mathbf{I}$ & 2 & 0 & $\mathbf{I}$ & 2 & 0 & $\mathbf{I}$ & 2 \\
\hline $0 \quad-0.49$ & . & . & 一 & - & $\mathbf{I}$ & 一 & - & - & 一 & 一 & 一 & 一 & 一 & - \\
\hline $0.50-0.99$ & .. & .. & - & I & 2 & 一 & 一 & I & 2 & $\mathbf{I}$ & 一 & I & - & - \\
\hline$I \cdot 00-I \cdot 49$ & . & .. & 一 & I & 8 & 一 & - & 4 & 3 & - & - & 4 & - & - \\
\hline$I \cdot 50-I \cdot 99$ & .. & .. & 一 & 6 & 16 & - & 3 & 3 & 10 & 一 & $\mathbf{I}$ & 5 & - & - \\
\hline $2 \cdot 00-2 \cdot 49$ & .. & .. & - & 13 & 19 & 一 & 6 & I & 17 & - & - & 18 & 一 & - \\
\hline $2 \cdot 50-2 \cdot 99$ & . & . & 一 & 29 & 25 & 一 & 7 & $\mathbf{I}$ & 63 & $\mathbf{I}$ & $\mathbf{I}$ & 38 & $\mathbf{I}$ & $\mathbf{I}$ \\
\hline $3 \cdot 00-3 \cdot 49$ & .. & $\cdots$ & 一 & 33 & $2 \mathbf{I}$ & - & 15 & 2 & 86 & $\mathbf{I}$ & 一 & 54 & I & I \\
\hline $3 \cdot 50-3 \cdot 99$ & . & .. & 一 & 18 & 9 & 一 & 4 & 3 & 83 & 3 & - & 48 & - & - \\
\hline $4 \cdot 00-4 \cdot 49$ & .. & .. & 一 & 5 & 4 & 一 & I & - & 33 & 2 & 一 & 27 & 一 & - \\
\hline $4 \cdot 50-4 \cdot 99$ & . & . & 一 & 2 & $\mathbf{I}$ & 一 & I & - & I6 & I & 一 & 9 & 一 & - \\
\hline $5 \cdot 00-5 \cdot 49$ & - & $\cdots$ & 一 & 3 & 一 & 一 & 一 & 一 & 4 & 一 & 一 & 4 & 一 & 一 \\
\hline $5 \cdot 50-5 \cdot 99$ & - & $\cdots$ & 一 & - & 一 & 一 & 一 & 一 & I & 一 & 一 & 一 & - & 一 \\
\hline Total. . & - & $\cdots$ & 一 & III & 106 & 一 & 37 & 15 & 318 & 9 & 2 & 208 & $\mathbf{I}$ & 2 \\
\hline Refusals & . & $\cdots$ & - & I & 3 & 一 & - & - & 12 & - & - & 2 & - & - \\
\hline Grand To & & .. & 一 & 112 & 109 & 一 & 37 & I5 & 330 & 9 & 2 & 210 & $\mathbf{I}$ & 2 \\
\hline Average ( 1 & $\cdots$ & .. & - & 3.08 & 2.59 & 一 & 2.99 & $2 \cdot 24$ & $3 \cdot 35$ & 3.47 & $2 \cdot 24$ & $3 \cdot 33$ & $3 \cdot 24$ & 3.00 \\
\hline S.D. (1.) & $\cdots$ & . & - & 0.77 & $0.8 I$ & - & 0.66 & I.06 & 0.76 & $I \cdot 16$ & 0.21 & 0.79 & 一 & 0.35 \\
\hline
\end{tabular}

relation between P.E.F.R. and phlegm grade for the four groups.

The P.E.F.R. in the dust-exposed group is $515.11 . / \mathrm{min}$. in the grade $0,476.31 . / \mathrm{min}$. in the grade I, and $408.61 . / \mathrm{min}$. in the grade II phlegm classes. The difference in P.E.F.R. between the grade $O$ and grade I phlegm groups is significant at the I \% level and that between grade I and grade II at the $0.001 \%$ level. Similarly, in the non-dustexposed group the figures are $521 \cdot 2 \mathrm{l} . / \mathrm{min}$., $455.6 \mathrm{l}$. $/ \mathrm{min}$., and $364.51 \mathrm{l} / \mathrm{min}$. respectively. The difference between the grade 0 and grade I groups is significant at the $0.01 \%$ level whereas that between the grade I and grade II groups is almost significant at the $5 \%$ level.

F.E.V.1.0, Age, and Dyspnoea Grade In the following tables breathlessness is presented in five grades according to the answers to the following questions in the questionnaire:

Are you ever troubled by shortness of breath when hurrying on the level or walking up a slight hill ? (14a)

Do you get short of breath walking with other people at an ordinary pace on the level ? (14b)

Do you stop for breath when walking at your own pace on the level ? (I4c)

Are you short of breath on washing or dressing ? (I4d)

Grade $I=$ No to $I 4$ a to $d$

Grade $2=$ Yes to $14 a$; no to $b$ to $d$

Grade $3=$ Yes to $14 a$ and $b$; no to $c$ and $d$

Grade $4=$ Yes to I4a to $c$; no to $d$

Grade $5=$ Yes to I4a to d.

Tables XI, XII, and XIII show this relationship for the three age groups, 35-44, 45-54, and 55 and over.

In general there is a negative association between the F.E.V. $\cdot 1 \cdot 0$ and grade of dyspnoea.

It will be noted, however, that the dust-exposed group, particularly the chronic bronchitics, show a higher proportion of grades 4 and 5 dyspnoea than do the non-dust-exposed group, and that grades 4 and 5 dyspnoea occur more frequently with higher F.E.V..$_{1 \cdot 0} \mathrm{~s}$ in the dust-exposed group.

P.E.F.R., Age, and Dyspnoea Grade A similar situation was found when the P.E.F.R. was 
TABLE X

Mran P.E.F.R. Correlated with PhLggm Grade in Those With and Without Chronic Bronchutis

\begin{tabular}{|c|c|c|c|c|c|c|c|c|c|c|c|c|c|c|}
\hline \multirow{3}{*}{\multicolumn{2}{|c|}{$\begin{array}{l}\begin{array}{c}\text { Mean P.E.F.R. } \\
(\text { l./min.) }\end{array} \\
\text { Phlegm Grale }\end{array}$}} & & \multicolumn{6}{|c|}{ Chronic Bronchitis } & \multicolumn{6}{|c|}{ No Bronchitis } \\
\hline & & & \multicolumn{3}{|c|}{ Dust-exposed } & \multicolumn{3}{|c|}{ No Exposure } & \multicolumn{3}{|c|}{ Dust-exposed } & \multicolumn{3}{|c|}{ No Exposure } \\
\hline & & .. & 0 & I & 2 & 0 & I & 2 & 0 & I & 2 & 0 & I & 2 \\
\hline 50- 99 & .. & .. & - & - & I & 一 & - & - & - & - & - & I & - & - \\
\hline $100-149$ & . & .. & - & - & I & - & - & $\mathbf{I}$ & 4 & - & - & $\mathbf{I}$ & - & - \\
\hline 150-199 & .. & .. & - & - & 3 & - & - & 4 & 2 & - & - & - & - & - \\
\hline $200-249$ & .. & .. & - & 3 & 6 & - & I & I & I & - & - & 2 & - & - \\
\hline $250-299$ & .. & .. & - & 2 & 6 & - & I & 2 & 3 & - & - & 3 & - & - \\
\hline 300-349 & .. & .. & - & 5 & 12 & - & 3 & - & 7 & - & - & 5 & - & - \\
\hline 350-399 & .. & .. & - & 9 & 16 & - & 4 & - & 13 & - & 2 & 7 & - & - \\
\hline $400-449$ & .. & .. & - & 22 & 19 & - & ro & $\mathbf{I}$ & 27 & $\mathbf{I}$ & - & II & - & I \\
\hline $450-499$ & .. & .. & - & 18 & 22 & - & 3 & - & 71 & 5 & - & 46 & I & - \\
\hline $500-549$ & .. & .. & 一 & 33 & 12 & 一 & 9 & 2 & 80 & I & - & 52 & - & $\mathbf{I}$ \\
\hline $550-599$ & .. & .. & - & 12 & 6 & - & 5 & 2 & 67 & I & - & 41 & - & - \\
\hline $600-649$ & .. & .. & - & 5 & 3 & - & I & 2 & 34 & I & - & 27 & - & - \\
\hline 650-699 & .. & .. & - & I & - & - & - & - & 14 & - & - & 9 & - & - \\
\hline $700-749$ & .. & .. & - & - & - & - & - & - & 5 & - & - & 3 & - & - \\
\hline 750-799 & .. & .. & - & $\mathbf{I}$ & - & - & - & - & - & - & - & I & - & - \\
\hline Total. . & $\cdots$ & .. & - & III & 107 & - & 37 & 15 & 328 & 9 & 2 & 209 & I & 2 \\
\hline Refusals & .. & .. & - & $\mathbf{I}$ & 2 & - & - & - & 2 & - & - & $\mathbf{I}$ & - & - \\
\hline \multicolumn{2}{|c|}{ Grand Total } & .. & - & II2 & 109 & 一 & 37 & 15 & 330 & 9 & 2 & 210 & $\mathbf{I}$ & 2 \\
\hline \multicolumn{2}{|c|}{ Average (1./min.) } & .. & - & $476 \cdot 3$ & $408 \cdot 6$ & - & $455 \cdot 6$ & $364 \cdot 5$ & $515 \cdot 1$ & $502 \cdot 3$ & $374 \cdot 5$ & $521 \cdot 2$ & $474 \cdot 5$ & 474.5 \\
\hline \multicolumn{2}{|c|}{ S.D. (1./min.) } & .. & - & $92 \cdot 8$ & III.4 & - & $92 \cdot 7$ & $191 \cdot 4$ & 97.5 & $59 \cdot 9$ & - & $98 \cdot 7$ & - & $70 \cdot 7$ \\
\hline
\end{tabular}

correlated with the dyspnoea grade for the several age groups (Table XIV).

In general there is a negative correlation between P.E.F.R. and dyspnoea grade.

\section{Discussion}

Ventilatory Function in Relation to Dust Exposure The results for the mean F.E.V.1.0, maximum F.E.V.1.0, mean P.E.F.R., and maximum P.E.F.R. (Tables I, III, V, and VII) show quite clearly that there is no significant difference in ventilatory capacity between miners and ex-miners on the one hand and non-miners on the other.

The differences between the dust-exposed and non-dust-exposed groups are very small: F.E.V.1.0 in chronic bronchitics $2.84 \mathrm{l}$. for the dust-exposed and $2.77 \mathrm{l}$. for the non-dust-exposed, and in the non-bronchitics 3.351 . and 3.33 1. respectively. The differences are of a similar order for the other tests.

On the other hand, with all four tests important differences in ventilatory function are demonstrated between chronic bronchitics and non-bronchitics as pooled groups (Tables II, IV, VI, and VIII). This is also true for both dust-exposed and non-dust-exposed groups considered separately. Table I shows that dust-exposed non-bronchitics have a mean F.E.V.1.0 3.351 . as against 2.84 l. for dust-exposed chronic bronchitics, while for the non-dust-exposed group the figures are 3.331 . and 2.77 1. respectively.

The same trends are found in the figures for the maximum F.E.V .1.0. In the dust-exposed groups the maximum F.E.V.1.0 is 3.43 l. in the nonbronchitics compared with 2.94 l. in the bronchitics, and in those without dust exposure 3.381 . compared with $2 \cdot 82$ l. respectively (Table III).

The same differences are found in the mean P.E.F.R (Table V), the dust-exposed group without bronchitis exceeding those with bronchitis (513.9 $1 . / \mathrm{min}$. compared with $443.1 \mathrm{l} / \mathrm{min}$.). In the nondust-exposed group the corresponding figures are $520.51 . / \mathrm{min}$. and $429.31 \mathrm{l} / \mathrm{min}$. The figures for maximum P.E.F.R. give a virtually identical picture.

Dust exposure appears to have no effect on ventilatory function over and above the role it may 
TABLE XI

Mran F.E.V.1.0 Correlated with Dyspnoea Grade, Age 35-44 Years

\begin{tabular}{|c|c|c|c|c|c|c|c|c|c|c|c|c|c|c|}
\hline & & & & & & & & Chronic & ronchit & & & & & \\
\hline & & & & & Dust-e & posed & & & & & No $E_{x}$ & osure & & \\
\hline Dyspnoea & $\mathrm{rad}$ & & $\boldsymbol{I}$ & 2 & 3 & 4 & 5 & Total & $\boldsymbol{I}$ & 2 & 3 & 4 & 5 & Total \\
\hline $0 \quad-0.49$ & $\cdots$ & . & - & - & - & - & - & - & - & - & - & - & - & - \\
\hline$I \cdot 00-I \cdot 49$ & $\cdots$ & . & 一 & I & - & - & - & $\mathbf{I}$ & - & - & - & - & - & - \\
\hline I·50-I·99 & . & . & - & 3 & 5 & - & I & 9 & - & - & - & - & - & - \\
\hline $2 \cdot 00-2 \cdot 49$ & . & . & 2 & 4 & 5 & I & - & 12 & - & $\mathbf{I}$ & - & - & - & I \\
\hline $2 \cdot 50-2 \cdot 99$ & - & . & 3 & II & 13 & 3 & 2 & 32 & - & $\mathbf{I}$ & I & - & - & 2 \\
\hline $3 \cdot 00-3 \cdot 49$ & $\cdots$ & . & 3 & 16 & 9 & 3 & 3 & 34 & 5 & 2 & - & - & - & 7 \\
\hline $3.50-3 \cdot 99$ & - & . & 7 & 13 & - & - & - & 20 & 2 & 3 & $\mathbf{I}$ & 一 & I & 7 \\
\hline $4 \cdot 00-4 \cdot 49$ & . & . & 4 & 2 & - & I & - & 7 & I & - & - & - & - & I \\
\hline $5 \cdot 00-5 \cdot 49$ & $\cdots$ & - & I & I & - & - & 一 & 2 & 一 & - & - & - & - & - \\
\hline $5 \cdot 50-5 \cdot 99$ & $\cdots$ & $\cdots$ & 一 & 一 & - & - & - & 一 & - & - & - & - & 一 & - \\
\hline Total. . & . & . & $2 I$ & 53 & 32 & 8 & 7 & I2I & 9 & 7 & 2 & - & $\mathbf{I}$ & 19 \\
\hline Refusals & . & . & - & $\mathbf{I}$ & - & - & - & I & - & 一 & - & - & - & - \\
\hline Grand Tc & & $\cdots$ & 21 & 54 & 32 & 8 & 7 & 122 & 9 & 7 & 2 & - & $\mathbf{I}$ & 19 \\
\hline Average ( & . & .. & $3 \cdot 60$ & $3 \cdot 20$ & $2 \cdot 65$ & 3.06 & 2.53 & 3.08 & 3.63 & $3 \cdot 24$ & $3 \cdot 24$ & - & $3 \cdot 74$ & 3.46 \\
\hline
\end{tabular}

TABLE XII

Mean F.E.V.1.0 Correlated with Dyspnota Grade, Age 45-54 Years

\begin{tabular}{|c|c|c|c|c|c|c|c|c|c|c|c|c|c|c|}
\hline \multirow{2}{*}{\multicolumn{3}{|c|}{$\underset{(l .)}{\operatorname{Mean}} \underset{F \cdot E \cdot V_{\cdot 1 \cdot 0}}{ }$}} & \multicolumn{12}{|c|}{ Chronic Bronchitis } \\
\hline & & & \multicolumn{6}{|c|}{ Dust-exposed } & \multicolumn{6}{|c|}{ No Exposure } \\
\hline \multicolumn{3}{|c|}{ Dyspnoea Grade } & $\boldsymbol{I}$ & 2 & 3 & 4 & 5 & Total & $I$ & 2 & 3 & 4 & 5 & Total \\
\hline $\begin{array}{ll}0 & -0.49\end{array}$ & .. & .. & - & - & 一 & - & - & - & - & - & - & - & - & - \\
\hline $0.50-0.99$ & .. & .. & - & - & I & - & - & I & - & - & - & - & - & - \\
\hline$I \cdot 00-I \cdot 49$ & .. & .. & - & - & I & - & 3 & 4 & - & - & $\mathbf{I}$ & - & $\mathbf{I}$ & 2 \\
\hline $1 \cdot 50-1 \cdot 99$ & .. & $\ldots$ & I & 2 & 4 & - & 3 & 10 & $\mathbf{I}$ & I & I & - & I & 4 \\
\hline $2 \cdot 00-2 \cdot 49$ & .. & .. & I & 2 & 4 & $\mathbf{I}$ & 4 & 12 & 2 & 3 & - & - & - & 5 \\
\hline $2 \cdot 50-2 \cdot 99$ & .. & .. & 3 & 4 & 6 & 3 & 3 & 19 & 3 & - & - & $\mathbf{I}$ & - & 4 \\
\hline $3 \cdot 00-3 \cdot 49$ & .. & .. & 6 & 4 & 5 & 2 & I & 18 & 2 & 5 & - & - & - & 7 \\
\hline $3.50-3.99$ & .. & .. & $\mathbf{I}$ & 2 & 3 & - & I & 7 & - & - & - & - & - & - \\
\hline $4 \cdot 00-4 \cdot 49$ & .. & .. & I & - & - & - & 一 & I & - & - & - & - & - & - \\
\hline $4 \cdot 50-4 \cdot 99$ & .. & .. & - & - & - & - & - & - & - & - & - & - & - & - \\
\hline $5 \cdot 00-5 \cdot 49$ & .. & .. & 一 & I & - & - & - & I & - & - & - & - & - & - \\
\hline $5 \cdot 50-5 \cdot 99$ & .. & .. & - & - & - & - & - & - & - & - & - & - & - & - \\
\hline Total.. & .. & .. & 13 & 15 & 24 & 6 & 15 & 73 & 8 & 9 & 2 & $\mathbf{I}$ & 2 & 22 \\
\hline Refusals & .. & .. & - & 一 & $\mathbf{I}$ & - & I & 2 & - & - & - & - & - & - \\
\hline \multicolumn{3}{|c|}{ Grand Total } & 13 & 15 & 25 & 6 & 16 & 75 & 8 & 9 & 2 & $\mathbf{I}$ & 2 & 22 \\
\hline \multicolumn{3}{|c|}{ Average (1.) .. } & 3.05 & $2 \cdot 98$ & 2.58 & 2.83 & $2 \cdot 21$ & 2.69 & $2 \cdot 64$ & $2 \cdot 74$ & I.5 & $2 \cdot 74$ & 1.5 & $2 \cdot 47$ \\
\hline
\end{tabular}


TABLE XI continued

\begin{tabular}{|c|c|c|c|c|c|c|c|c|c|c|c|c|c|c|}
\hline \multirow{2}{*}{\multicolumn{3}{|c|}{$\underset{(l .)}{\operatorname{Mean} F . E . V_{\cdot 1 \cdot 0}}$}} & \multicolumn{12}{|c|}{ No Bronchitis } \\
\hline & & & \multicolumn{6}{|c|}{ Dust-exposed } & \multicolumn{6}{|c|}{ No Exposure } \\
\hline \multicolumn{3}{|c|}{ Dyspnoea Grade } & $I$ & 2 & 3 & 4 & 5 & Total & $I$ & 2 & 3 & 4 & 5 & Total \\
\hline $\begin{array}{ll}0 & -0.49\end{array}$ & .. & .. & - & - & - & - & - & - & - & - & - & - & - & - \\
\hline $0.50-0.99$ & .. & .. & - & - & - & - & I & I & - & - & - & - & - & - \\
\hline $\mathrm{I} \cdot 00-\mathrm{I} \cdot 49$ & .. & .. & - & - & - & - & - & - & - & - & - & - & - & - \\
\hline I. $50-1 \cdot 99$ & .. & .. & $\mathbf{I}$ & - & - & - & - & I & - & - & $\mathbf{I}$ & - & - & I \\
\hline $2 \cdot 00-2 \cdot 49$ & .. & .. & 2 & $\mathbf{I}$ & - & - & - & 3 & I & $\mathbf{I}$ & I & - & - & 3 \\
\hline $2 \cdot 50-2 \cdot 99$ & $\cdots$ & .. & I2 & 8 & 2 & I & - & 23 & 6 & 3 & $\mathbf{I}$ & - & - & 10 \\
\hline $3 \cdot 00-3 \cdot 49$ & .. & .. & 26 & 18 & 5 & 2 & I & 52 & $2 \mathrm{I}$ & 7 & - & - & - & 28 \\
\hline $3 \cdot 50-3 \cdot 99$ & .. & .. & 33 & 22 & 4 & - & I & 60 & 26 & 7 & I & - & - & 34 \\
\hline $4 \cdot 00-4 \cdot 49$ & .. & .. & 19 & 8 & I & - & I & 29 & 20 & 4 & - & - & - & 24 \\
\hline $4 \cdot 50-4 \cdot 99$ & .. & .. & IO & 2 & I & - & - & 13 & 5 & 2 & - & - & - & 7 \\
\hline $5 \cdot 00-5 \cdot 49$ & .. & .. & 2 & I & - & - & - & 3 & 3 & - & - & - & - & 3 \\
\hline $5 \cdot 50-5 \cdot 99$ & .. & .. & I & - & - & - & - & I & - & - & - & - & - & - \\
\hline Total. . & .. & .. & 106 & 60 & 13 & 3 & 4 & 186 & 82 & 24 & 4 & - & - & I10 \\
\hline Refusals & .. & .. & - & $\mathbf{I}$ & $\mathbf{I}$ & 2 & - & 4 & - & - & - & - & - & - \\
\hline \multicolumn{3}{|c|}{ Grand Total } & 106 & $6 I$ & 14 & 5 & 4 & 190 & 82 & 24 & 4 & - & - & IIO \\
\hline \multicolumn{3}{|c|}{ Average (1.) .. } & 3.69 & 3.56 & 3.51 & 3.08 & 3.00 & $3.6 \mathrm{I}$ & $3 \cdot 76$ & 3.58 & 2.62 & - & - & 3.68 \\
\hline
\end{tabular}

TABLE XII continued

\begin{tabular}{|c|c|c|c|c|c|c|c|c|c|c|c|c|c|c|}
\hline \multirow{3}{*}{\multicolumn{3}{|c|}{$\begin{array}{c}\begin{array}{c}\text { Mean F.E.V.V.1·0 } \\
(l .)\end{array} \\
\text { Dyspnoea Grade }\end{array}$}} & \multicolumn{12}{|c|}{ No Bronchitis } \\
\hline & & & \multicolumn{6}{|c|}{ Dust-exposed } & \multicolumn{6}{|c|}{ No Exposure } \\
\hline & & & \multirow{2}{*}{$\frac{I}{-}$} & \multirow{2}{*}{$\frac{2}{-}$} & \multirow{2}{*}{$\frac{3}{-}$} & \multirow{2}{*}{$\frac{4}{-}$} & \multirow{2}{*}{5} & \multirow{2}{*}{$\frac{\text { Total }}{-}$} & \multirow{2}{*}{$\frac{I}{-}$} & \multirow{2}{*}{$\frac{2}{-}$} & \multirow[t]{2}{*}{3} & \multirow{2}{*}{$\begin{array}{r}4 \\
-\end{array}$} & \multirow{2}{*}{$\frac{5}{-}$} & Total \\
\hline $0 \quad-0.49$ & .. & .. & & & & & & & & & & & & \\
\hline $0.50-0.99$ & .. & .. & - & $\mathbf{I}$ & - & - & - & I & - & - & - & - & - & - \\
\hline I.00-1. 49 & .. & .. & - & - & - & I & - & I & - & - & - & - & - & - \\
\hline I.50-I.99 & .. & .. & - & I & 4 & - & - & 5 & I & - & - & - & - & I \\
\hline $2 \cdot 00-2 \cdot 49$ & .. & .. & - & 5 & I & I & 2 & 9 & 2 & 5 & 2 & - & $\mathbf{I}$ & 10 \\
\hline $2 \cdot 50-2 \cdot 99$ & . & .. & Io & 14 & Io & - & 2 & 36 & I I & 8 & I & - & I & $2 \mathrm{I}$ \\
\hline $3 \cdot 00-3 \cdot 49$ & .. & .. & 13 & 10 & 4 & 2 & - & 29 & 15 & 6 & 3 & - & - & 24 \\
\hline $3 \cdot 50-3 \cdot 99$ & .. & .. & 13 & 8 & 4 & - & - & 24 & 6 & I & 2 & - & $\mathbf{I}$ & I0 \\
\hline $4 \cdot 00-4 \cdot 49$ & .. & .. & 2 & 3 & - & - & - & 5 & 2 & I & - & - & - & 3 \\
\hline $4 \cdot 50-4 \cdot 99$ & .. & .. & 2 & 2 & - & - & - & 4 & I & I & - & - & - & 2 \\
\hline $5 \cdot 00-5 \cdot 49$ & .. & .. & - & $\mathbf{I}$ & - & - & - & I & I & - & - & - & - & I \\
\hline $5 \cdot 50-5 \cdot 99$ & .. & .. & - & - & - & - & - & - & - & - & - & - & - & - \\
\hline Total.. & .. & .. & 39 & 45 & 23 & 4 & 4 & II & 39 & 22 & 8 & - & 3 & 72 \\
\hline Refusals & .. & .. & 3 & 3 & - & - & - & 6 & - & - & - & - & - & - \\
\hline Grand To & & .. & 42 & 48 & 23 & 4 & 4 & I $2 I$ & $39^{\circ}$ & 22 & 8 & - & 3 & 72 \\
\hline Average (1. & .. & .. & 3.40 & $3 \cdot 16$ & $2 \cdot 8 \mathrm{I}$ & 2.50 & $2 \cdot 50$ & $3 \cdot 12$ & 3.23 & $2 \cdot 97$ & 3.06 & - & 2.91 & $3 \cdot 12$ \\
\hline
\end{tabular}


TABLE XIII

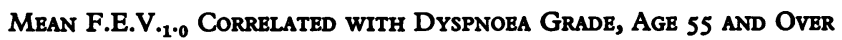

\begin{tabular}{|c|c|c|c|c|c|c|c|c|c|c|c|c|c|c|}
\hline & & & & & & & & hronic & onchit & & & & & \\
\hline Mean & E.V & & & & Dust-e & osed & & & & & No $E$ & sure & & \\
\hline Dyspnoea & rade & & $\boldsymbol{I}$ & 2 & 3 & 4 & 5 & Total & $\boldsymbol{I}$ & 2 & 3 & 4 & 5 & Total \\
\hline $0 \quad-0.50$ & . & . & - & - & - & - & $\mathbf{I}$ & I & - & - & - & - & 一 & - \\
\hline $0.50-0.99$ & .. & .. & - & - & I & - & - & $\mathbf{I}$ & 一 & - & 一 & - & I & I \\
\hline$I \cdot 00-I \cdot 49$ & . & .. & 一 & $\mathbf{I}$ & I & I & I & 4 & - & - & 一 & I & I & 2 \\
\hline $1 \cdot 50-1 \cdot 99$ & .. & .. & 一 & - & 一 & 2 & I & 3 & $\mathbf{I}$ & - & $\mathbf{I}$ & 一 & - & 2 \\
\hline $2 \cdot 00-2 \cdot 49$ & .. & .. & 2 & 2 & $\mathbf{I}$ & I & 2 & 8 & - & $\mathbf{I}$ & 一 & - & - & I \\
\hline $2 \cdot 50-2 \cdot 99$ & . & . & - & $\mathbf{I}$ & 2 & - & - & 3 & $\mathbf{I}$ & $\mathbf{I}$ & 一 & - & - & 2 \\
\hline $3 \cdot 00-3 \cdot 49$ & .. & .. & - & I & I & - & - & 2 & 2 & - & I & 一 & - & 3 \\
\hline $3.50-3.99$ & .. & .. & - & - & - & - & - & - & - & 一 & - & 一 & - & - \\
\hline $4 \cdot \infty-4 \cdot 49$ & .. & .. & 一 & I & 一 & 一 & 一 & I & 一 & - & 一 & 一 & 一 & - \\
\hline $4 \cdot 50-4 \cdot 99$ & .. & .. & - & 一 & 一 & 一 & - & - & - & - & - & - & - & 一 \\
\hline $5 \cdot 00-5 \cdot 49$ & . & . & 一 & - & - & 一 & - & - & - & - & 一 & 一 & 一 & 一 \\
\hline $5 \cdot 50-5 \cdot 99$ & .. & $\cdots$ & - & 一 & 一 & 一 & 一 & 一 & - & - & - & - & - & - \\
\hline Total. . & . & . & 2 & 6 & 6 & 4 & 5 & 23 & 4 & 2 & 2 & I & 2 & II \\
\hline Refusals & . & .. & - & - & - & 一 & I & $\mathbf{I}$ & 一 & - & - & - & - & - \\
\hline Grand To & & .. & 2 & 6 & 6 & 4 & 6 & 24 & 4 & 2 & 2 & I & 2 & II \\
\hline Average ( & & .. & $2 \cdot 24$ & $2 \cdot 66$ & $2 \cdot 16$ & $I \cdot 74$ & $1 \cdot 5 c$ & $2 \cdot 08$ & $2 \cdot 74$ & $2 \cdot 5$ & 2.5 & $I \cdot 24$ & $1 \cdot \infty$ & $2 \cdot 20$ \\
\hline
\end{tabular}

TABLE XIV

Mean P.E.F.R. Correlated with Dyspnoea Grade

\begin{tabular}{|c|c|c|c|c|c|c|c|c|c|c|c|c|}
\hline \multirow{3}{*}{ Dyspnoea Grade } & \multicolumn{12}{|c|}{ Chronic Bronchitis } \\
\hline & \multicolumn{6}{|c|}{ Dust-exposed } & \multicolumn{6}{|c|}{ No Exposure } \\
\hline & $\boldsymbol{I}$ & 2 & 3 & 4 & 5 & Total & $\boldsymbol{I}$ & 2 & 3 & 4 & 5 & Total \\
\hline $\begin{array}{l}\text { Age Group } 35-44 \\
\text { Total } \\
\begin{array}{l}\text { Refusals } \\
\text { Grand Total }\end{array} \\
\begin{array}{l}\text { Average P.E.F.R. } \\
\text { (1./min.) }\end{array}\end{array}$ & $\begin{array}{l}\frac{21}{21} \\
508\end{array}$ & $\begin{array}{r}53 \\
1 \\
54 \\
435\end{array}$ & $\begin{array}{l}\frac{32}{32} \\
413\end{array}$ & $\begin{array}{r}\frac{8}{8} \\
443\end{array}$ & $\begin{array}{r}\frac{7}{7} \\
417\end{array}$ & $\begin{array}{r}121 \\
1 \\
122 \\
464\end{array}$ & $\begin{array}{r}\frac{9}{9} \\
497\end{array}$ & $\begin{array}{r}\frac{7}{7} \\
510\end{array}$ & $\begin{array}{r}\frac{2}{2} \\
525\end{array}$ & $\begin{array}{l}- \\
-\end{array}$ & $\begin{array}{r}\frac{1}{1} \\
525\end{array}$ & $\begin{array}{l}\frac{19}{19} \\
506\end{array}$ \\
\hline $\begin{array}{l}\text { Age Group } 45-54 \\
\text { Total } \quad .\end{array}$ & $\begin{array}{l}\frac{13}{13} \\
482\end{array}$ & $\begin{array}{l}\frac{15}{15} \\
455\end{array}$ & $\begin{array}{l}\frac{25}{25} \\
410\end{array}$ & $\begin{array}{r}\frac{6}{6} \\
415\end{array}$ & $\begin{array}{r}15 \\
1 \\
16 \\
358\end{array}$ & $\begin{array}{r}74 \\
1 \\
75 \\
\\
426\end{array}$ & $\begin{array}{r}\frac{8}{8} \\
48 I\end{array}$ & $\begin{array}{r}\frac{9}{9} \\
430\end{array}$ & $\begin{array}{r}\frac{2}{2} \\
200\end{array}$ & $\begin{array}{r}\frac{I}{I} \\
425\end{array}$ & $\begin{array}{r}\frac{2}{2} \\
200\end{array}$ & $\begin{array}{r}\frac{22}{22} \\
406\end{array}$ \\
\hline $\begin{array}{l}\text { Age Group } 55 \text { and } \\
\text { Tover } \\
\begin{array}{l}\text { Refusals } \\
\text { Grand Total }\end{array} \\
\begin{array}{l}\text { Average P.E.F.R. } \\
\text { (l./min.) }\end{array}\end{array}$ & $\begin{array}{r}\frac{2}{2} \\
450\end{array}$ & $\begin{array}{r}\frac{6}{6} \\
457\end{array}$ & $\frac{6}{6}$ & $\frac{4}{4}$ & $\begin{array}{l}5 \\
1 \\
6\end{array}$ & $\begin{array}{r}23 \\
1 \\
24\end{array}$ & $\frac{4}{4}$ & $\frac{2}{2}$ & $\frac{2}{2}$ & $\frac{I}{I}$ & $\frac{2}{2}$ & $\frac{\text { II }}{\text { II }}$ \\
\hline
\end{tabular}


TABLE XIII continued

\begin{tabular}{|c|c|c|c|c|c|c|c|c|c|c|c|c|c|c|}
\hline \multirow{2}{*}{\multicolumn{3}{|c|}{$\underset{(l .)}{\text { Mean }} \underset{\text { F.E. }}{F \cdot 1 \cdot 0}$}} & \multicolumn{12}{|c|}{ No Bronchitis } \\
\hline & & & \multicolumn{6}{|c|}{ Dust-exposed } & \multicolumn{6}{|c|}{ No Exposure } \\
\hline \multicolumn{3}{|c|}{ Dyspnoea Grade } & $I$ & 2 & 3 & 4 & 5 & Total & $I$ & 2 & 3 & 4 & 5 & Total \\
\hline $0 \quad-0.50$ & .. & .. & - & - & - & - & - & - & - & - & - & - & - & - \\
\hline $0.50-0.99$ & .. & .. & - & - & $\mathbf{I}$ & - & - & $\mathbf{I}$ & - & $\mathbf{I}$ & - & - & - & $I$ \\
\hline$I \cdot 00-1 \cdot 49$ & .. & .. & $\mathbf{r}$ & - & I & - & - & 2 & - & 2 & $\mathbf{I}$ & - & $\mathbf{I}$ & 4 \\
\hline I.50-1.99 & .. & .. & $\mathbf{I}$ & 2 & I & - & I & 5 & 2 & I & - & - & - & 3 \\
\hline $2 \cdot 00-2 \cdot 49$ & . & .. & - & I & 3 & - & I & 5 & - & 3 & 2 & - & - & 5 \\
\hline $2 \cdot 50-2 \cdot 99$ & .. & .. & I & 2 & - & $\mathbf{I}$ & 2 & 6 & 8 & - & - & - & - & 8 \\
\hline $3 \cdot 00-3 \cdot 49$ & .. & .. & 3 & $\mathbf{I}$ & 2 & - & - & 6 & 2 & 2 & - & - & - & 4 \\
\hline $3 \cdot 50-3 \cdot 99$ & .. & .. & I & - & $\mathbf{I}$ & - & - & 2 & 2 & I & I & - & - & 4 \\
\hline $4 \cdot 00-4 \cdot 49$ & .. & .. & I & - & - & - & - & I & - & - & - & - & - & - \\
\hline $4 \cdot 50-4 \cdot 99$ & .. & .. & - & 一 & - & - & - & - & - & - & - & - & - & - \\
\hline $5 \cdot 00-5 \cdot 49$ & .. & .. & - & - & - & - & - & - & - & - & - & - & - & - \\
\hline $5 \cdot 50-5 \cdot 99$ & .. & .. & - & - & - & - & 一 & - & - & - & - & - & - & - \\
\hline Total.. & .. & .. & 8 & 6 & 9 & I & 4 & 28 & 14 & ro & 4 & - & I & 29 \\
\hline Refusals & $\cdots$ & .. & $\mathbf{I}$ & - & 一 & - & $\mathbf{I}$ & 2 & $\mathbf{I}$ & I & 一 & - & - & 2 \\
\hline Grand To & & .. & 9 & 6 & 9 & I & 5 & 30 & 15 & II & 4 & - & I & 31 \\
\hline Average ( & .. & .. & 2.93 & $2 \cdot 4 \mathrm{I}$ & $2 \cdot 30$ & $2 \cdot 74$ & $2 \cdot 37$ & 2.53 & $2 \cdot 82$ & $2 \cdot 20$ & $2 \cdot 37$ & - & $\mathrm{I} \cdot 24$ & - \\
\hline
\end{tabular}

TABLE XIV continued

\begin{tabular}{|c|c|c|c|c|c|c|c|c|c|c|c|c|}
\hline \multirow{3}{*}{ Dyspnoea Grade } & \multicolumn{12}{|c|}{ No Bronchitis } \\
\hline & \multicolumn{6}{|c|}{ Dust-exposed } & \multicolumn{6}{|c|}{ No Exposure } \\
\hline & $I$ & 2 & 3 & 4 & 5 & Total & $\boldsymbol{I}$ & 2 & 3 & 4 & 5 & Total \\
\hline 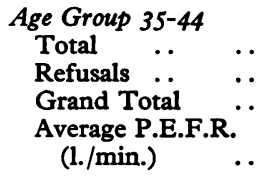 & $\begin{array}{l}\frac{106}{106} \\
536\end{array}$ & $\begin{array}{l}\frac{61}{61} \\
536\end{array}$ & $\begin{array}{l}\frac{14}{14} \\
517\end{array}$ & $\frac{5}{5}$ & $\begin{array}{r}\frac{4}{4} \\
562\end{array}$ & $\begin{array}{l}\frac{190}{190} \\
534\end{array}$ & $\begin{array}{l}\frac{82}{82} \\
555\end{array}$ & $\begin{array}{l}\frac{24}{24} \\
554\end{array}$ & $\begin{array}{r}\frac{4}{4} \\
512\end{array}$ & 二 & $\begin{array}{l}- \\
-\end{array}$ & $\begin{array}{l}110 \\
110 \\
553\end{array}$ \\
\hline $\begin{array}{cc}\text { Age Group } & 45-54 \\
\text { Total } & .5 \\
\text { Refusals } & \ldots \\
\text { Grand Total } & \ldots \\
\begin{array}{l}\text { Average P.E.F.R. } \\
\text { (1./min.) }\end{array}\end{array}$ & $\begin{array}{r}41 \\
1 \\
42 \\
537\end{array}$ & $\begin{array}{r}\frac{48}{48} \\
516\end{array}$ & $\begin{array}{l}\frac{23}{23} \\
459\end{array}$ & $\begin{array}{r}\frac{4}{4} \\
362\end{array}$ & $\frac{4}{4}$ & $\begin{array}{r}120 \\
1 \\
121 \\
505\end{array}$ & $\begin{array}{r}\frac{39}{39} \\
516\end{array}$ & $\begin{array}{l}\frac{22}{22} \\
504\end{array}$ & $\frac{8}{8}$ & 二 & $\begin{array}{r}\frac{3}{3} \\
475\end{array}$ & $\frac{72}{72}$ \\
\hline 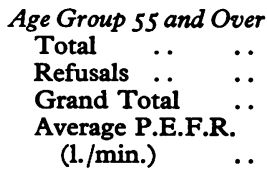 & $\frac{9}{9}$ & $\frac{6}{6}$ & $\frac{9}{9}$ & $\frac{\mathbf{I}}{\mathbf{I}}$ & $\begin{array}{l}4 \\
1 \\
5\end{array}$ & $\begin{array}{r}29 \\
1 \\
30\end{array}$ & $\begin{array}{r}14 \\
1 \\
15\end{array}$ & $\frac{I I}{\text { II }}$ & $\frac{4}{4}$ & 二 & $\frac{\mathbf{I}}{\mathbf{I}}$ & $\begin{array}{r}30 \\
1 \\
31\end{array}$ \\
\hline
\end{tabular}


play in causing chronic bronchitis in miners (Sluis-Cremer et al., 1967).

This conclusion is strongly supported by the findings when the mean F.E.V.1.0 ${ }_{\cdot 1 \cdot 0}$ and P.E.F.R. are plotted against phlegm grade. No significant differences appear between the dust-exposed and non-dust-exposed groups for grade 0 , grade I, or grade II phlegm.

On the other hand, increasing severity of chronic bronchitis as reflected in phlegm grade is associated with a fall in both mean F.E.V.1.0 and mean P.E.F.R. (Tables IX and X).

Ventilatory Function in Relation to Dyspnoea Grade When F.E.V.1.0 and P.E.F.R. are plotted against dyspnoea grade in the four groups (chronic bronchitis, dust-exposed and nondust-exposed and non-bronchitic dust-exposed and non-dust-exposed) standardizing for age, there is a negative correlation with dyspnoea grade but an important anomaly appears (Tables XI, XII, XIII, and XIV).

In all age groups there appear to be more persons suffering from grades 4 and 5 dyspnoea among miners than non-miners irrespective of whether they have chronic bronchitis or not. For instance in the 35-44 year age group (Table XI) I 5 out of 121 $(12.4 \%)$ reported grade 4 or 5 dyspnoea among the dust-exposed bronchitics, and seven out of 186 $(2 \cdot 8 \%)$ among the dust-exposed non-bronchitics, whereas only one out of $19(5.3 \%)$ non-dust-exposed chronic bronchitics and none out of I IO non-dustexposed non-bronchitics reported these degrees of dyspnoea.

For the 45-54 year age group the figures are 21 out of $73(28.8 \%)$ and three out of $22(13.6 \%)$ for chronic bronchitics dust- and non-dust-exposed respectively, and eight out of $115(7 \%)$ and three out of $72(4 \cdot 2 \%)$ for the non-bronchitic dust- and non-dust-exposed respectively.

For the group 55 and over, the figures are nine out of $23(39.6 \%)$ and three out of II $(27.2 \%)$ for the chronic bronchitics dust- and non-dust-exposed, and five out of $28(17.9 \%)$ and one out of $29(3.4 \%)$ for the non-bronchitic group.

These findings are at variance with the demonstration that there is no significant difference between the mean F.E.V.1.0 and P.E.F.R. among chronic bronchitic dust-exposed and non-dust-exposed groups or among non-bronchitic dust-exposed and non-dust-exposed groups.

As the dyspnoea grade is a personal subjective assessment this unexpected finding could be due to bias among miners and ex-miners. Good reasons for such bias to render 'high' answers to questions on dyspnoea exist for miners. There is acute, even excessive awareness among them as a community of the potentially harmful effects of breathing silica dust. This is partly induced at home (many of today's miners had a miner among their older relatives), partly by regular questioning on respiratory symptoms at the compulsory annual periodical examination, and partly by a desire for compensation.

That bias is in fact the reason for this anomaly is supported by a close study of Tables XI, XII, and XIII. It will be noted that the dust-exposed groups have high grades of dyspnoea relative to the ventilatory capacity. Thus in the age group 35-44, grades 4 or 5 dyspnoea are found associated with an F.E.V.1.0 of 2.01 . or over in 19 of 307 men in the dust-exposed group and only once in 129 men in the non-dustexposed group.

Similarly, in the age group $45-54$, grades 4 or 5 dyspnoea occur in the same F.E.V.1.0 range 22 times in 188 miners but in only four of 94 non-miners. In the age group 55 years and over, the corresponding figures are seven of $5 \mathrm{I}$ miners and none of 40 nonminers. A similar picture is found in the relation of the P.E.F.R. to the dyspnoea grade.

The possibility that some parameter of lung function not measured by the F.E.V.1.0 ${ }_{\cdot 1}$ or P.E.F.R. is affected by dust exposure cannot be entirely ruled out but appears unlikely as the predominant clinical and physiological aberrations in silicotics are those of airway obstruction.

Relationship between the Tests Applied A striking similarity between the mean F.E.V. $\cdot_{\cdot 1 \cdot 0}$ and the maximum F.E.V.1.0 becomes apparent on comparing Tables I and III and Tables II and IV. This also applies to the standard deviations and the percentage distributions of the volume categories.

The same close agreement in mean flow rate is noted for the mean and maximum P.E.F.R. when Tables V and VII and VI and VIII are compared.

It seems clear that in fact no advantage accrues by calculating both parameters in a study of this kind and that it matters little which is chosen.

The close agreement of these results probably also testifies to the consistency with which the field officer carried out these tests and to the degree of co-operation in performing them which was obtained from this population.

In this population the trend of the results in the different groups is identical for both the F.E.V.1.0 and the P.E.F.R.

International Comparisons Table XV shows the indirect M.B.C. in the 55-64 year age group or a similar age group as reported from various surveys in other countries. The South African figures are 
TABLE XV

MEAN INDIRECT M.B.C. IN VARIOUS SURVEYS

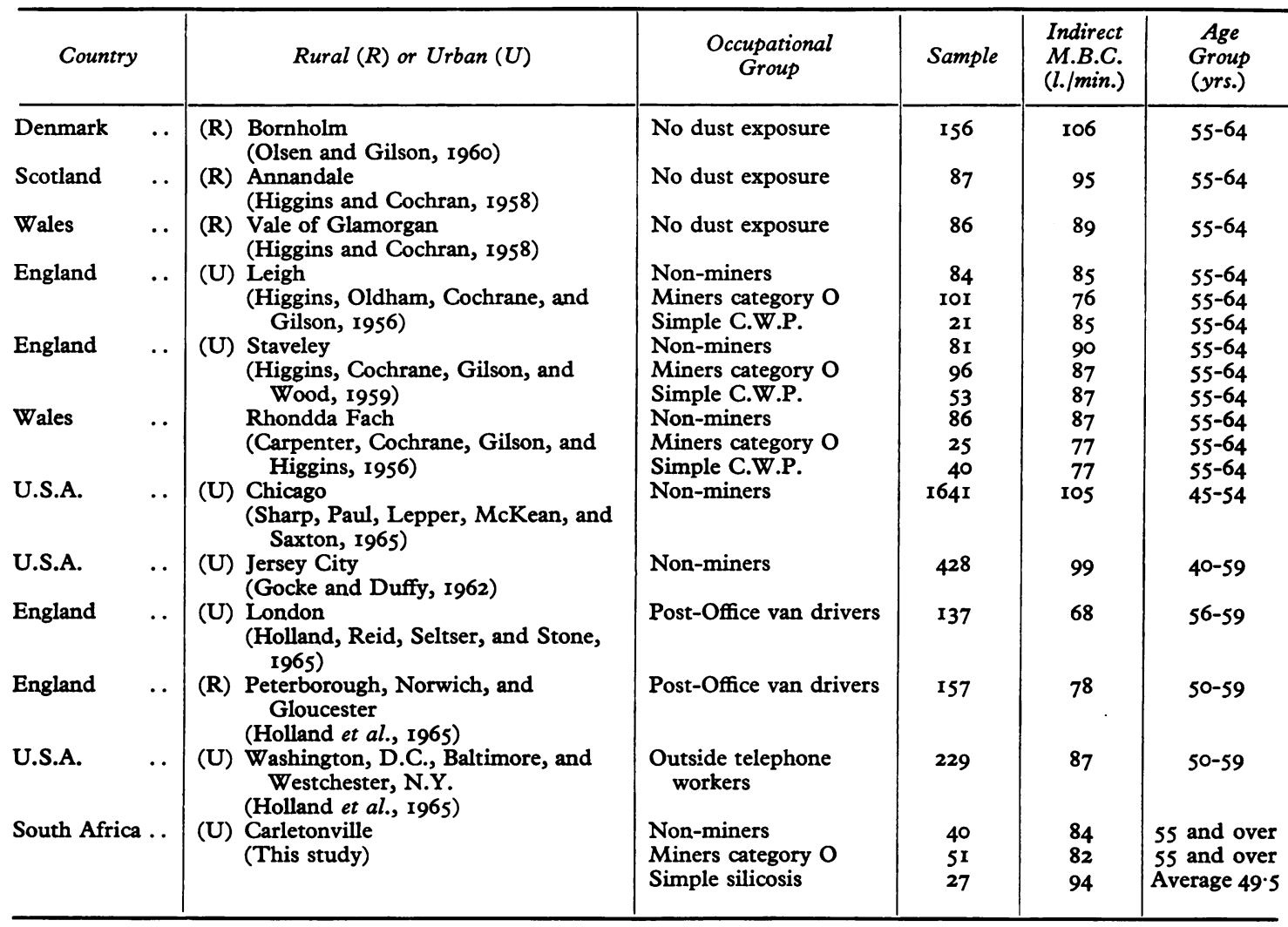

C.W.P. = coalworkers' pneumoconiosis.

comparable to those found elsewhere. The somewhat high figure for the group with simple silicosis is in part attributable to the fact that they are a younger age group.

We gladly acknowledge the outstanding manner in which Mr. C. S. Rautenbach, the field officer for this survey, acquitted himself of his task.

We appreciate the advice and assistance given by Dr. J. C. Gilson at various times before and during the survey.

\section{REFERENCES}

Carpenter, R. G., Cochrane, A. L., Gilson, J. C., and Higgins, I. T. T. (1956). Brit. F. industr. Med., 13, 166.
Gocke, T. M., and Duffy, B. J. (1962). Arch. intern. Med., 110, 606

Higgins, I. T. T., and Cochran, J. B. (1958). Tubercle (Edinb.), 39, 296.

-, Cochrane, A. L., Gilson, J. C., and Wood, C. H. (1959). Brit. F. industr. Med., 16, 255.

-, Oldham, P. D., Cochrane, A. L., and Gilson, J. C. (1956). Brit. med. F., 2, 904.

Holland, W. W., Reid, D. D., Seltser, R., and Stone, R. W. (1965). Arch. environm. Hlth, 10, 338.

McKerrow, C. B., McDermott, M., and Gilson, J. C. (1960). Lancet, $\mathrm{I}, 149$.

Olsen, H. C., and Gilson, J. C. (1960). Brit. med. F., 1, 450.

Sharp, J. T., Paul, O., Lepper, M. H., McKean, H., and Saxton, G. A. (1965). Amer. Rev. resp. Dis., 91, 510.

Sluis-Cremer, G. K., Walters, L. G., and Sichel, H. S. (1967) Brit. F. industr. Med., 24, I. 